\title{
Yeni Medya ve Temsil: İnternet Gazeteciliğinde \\ Toplumsal Cinsiyet Kimliklerinin Sunumu ${ }^{1-2}$
}

\author{
New Media And Representation: \\ Presentation of Gender Identity In Internet Journalism
}

\author{
Fatih SÖĞÜT ${ }^{3}$, Vahit ILHAN ${ }^{4}$
}

\section{Öz}

İnternetin hayatımıza girmesiyle birlikte pek çok alanda olduğu gibi habercilik pratiklerinde de önemli değişimler olmuştur. İnternet gazetesi denilen çevrimiçi habercilik yapmaya imkân tanıyan yeni bir medya türü ortaya çıkmıştır. Bu çalışmada yeni bir medya türü olarak görülen internet gazetesi ve temsil konu edilmiştir. Özellikle internet gazetelerinde cinsiyet kimliklerinin nasıl inşa edildiği sorusuna cevap aranmaktadır. Bu çalışma kapsamında, internet gazetelerinde cinsiyet kimliklerinin görünürlük seviyesini, hangi cinsiyetin ne ölçüde görünür kılındığını ve nasıl görüntülendiğini tespit etmek üzere nitel içerik çözümlemesi yapılmıştır. Bu çalışma kapsamında sistematik yöntemle seçilen örneklemin belirlenmesinde kullanılan ölçüt internet gazetelerinin tıklanma sayısı olup, tıklanma bilgileri internet reyting verilerini yayınlayan Alexa.com adlı siteden alınmıştır. Bu doğrultuda, tıklanma sayısı en fazla olan ilk üç internet sitesi belirlenmiştir. Bu siteler, tıklanma sayısı sırasıyla "milliyet.com.tr", "hurriyet.com.tr" ve "sabah.com.tr" dir. Elde edilen araştırma bulgularına göre kadın kimliğinin internet gazetelerinde daha çok magazin malzemesi olarak kullanıldığı, aynı zamanda bu eğilim sonucunda, internet gazetelerinde ağılıklı olarak eğlence sektöründe yer alan 20-35 yaş arası kadınların görünür kılındığı tespit edilmiştir. İncelenen internet gazetelerinde ön plana çıkan erkeğin temsil özellikleri; modayı ve teknolojik gelişmeleri takip eden, delikanlı, baba ve eş, sert, dayanıklı, güçlü erkek şeklinde belirginleşmiştir ve ataerkil düzendeki erkek egemenliği bu temsil özellikleriyle meşrulaştırılmıştır.

Anahtar Kelimeler: İnternet Gazeteciliği, Kimlik, Temsil, Toplumsal Cinsiyet, Medya

\section{Abstract}

It is a reality that the Internet has entered into every aspect of our life in a very short time. With the widespread use of the Internet, online journalism has become a type of journalism that publishes news on the Internet, and newspapers, television and radio organizations have started to publish news on this field. In this study, internet journalist and representation, which is seen as a new medium of mass communication, has been discussed. In particular, the question is how to construct gender identities in internet newspapers. In this study, a content analysis was conducted to determine the level of visibility of gender identities in internet newspapers, the gender of the gender, the extent to which it was made visible and how it was displayed. According to the research findings, it was found that women's identity was used more as magazine material in internet newspapers and at the same time, as a result of this tendency, it was found that 20-35 year old women mainly in entertainment sector in internet newspapers are visible. It is possible to say that, in the internet newspapers, women are mainly represented as "magazine object" and "sexual object" when the women's photographs are taken into consideration and the clothing levels of the displayed women are taken into account. The characteristics of the representation of the man in the foreground in internet newspapers examined; fashion and technology, the young man, the father and the spouse are in a strong, strong, strong male figure, and the patriarchal male domination is legitimized by these representations.

Key Words: Internet Journalism, Identity, Representation, Gender, Media

Araștırma Makalesi (Research Article)

Gönderim Tarihi (Received): 25.02.2019

Kabul Tarihi (Accepted): 27.02.2021
Atıf (cite as): Söğüt, F. ve İhan, V. (2021). “Yeni Medya ve Temsil: İnternet Gazeteciliğinde Toplumsal Cinsiyet Kimliklerinin Sunumu". Akdeniz Üniversitesi İletișim Fakültesi Dergisi, (35), s. 510-527, D0I: 10.31123/akil.953251

1 Bu makale, Erciyes Üniversitesi Sosyal Bilimler Enstitüsü Iletişim Bilimleri ABD tarafından 2018 yılında kabul edilen aynı isimli doktora tezinden üretilmiştir.

2 Bu makale, dergimizin 31. sayısında aynı başıkla yayınlanmış ve Düzeltme / Erratum alanında belirtilen gerekçelerden dolayı bu sayıda düzeltilmiş haliyle yeniden yayımlanmaktadır.

3 Dr. Öğr. Üyesi Kırklareli Üniversitesi Sosyal Bilimler Meslek Yüksekokulu, fatihsogut17@mynet.com Orcid ID: 0000-0001-6529-9056

4 Prof. Dr. Vahit ILHAN, Erciyes Üniversitesi İletişim Fakültesi Gazetecilik ABD, vilhan@erciyes.edu.tr, 0000-0002-2765-9652 


\section{Giriș}

İletişim araştırmalarının tarihsel gelişiminde yapılan pek çok çalışmada medyanın birey ve toplum üzerinde olan etkileri araştırılmıştır. Bu araştırmalar, medya etkisinin yalnızca siyasi tercihler veya tüketim alışkanlıklarıyla sınırlı kalmadığını, aynı zamanda kendilerinin ve öteki bireylerin kim olduğuna ve hangi kimlik özelliklerine sahip olması gerektiğine ilişkin beklentilerinin şekillenmesinde de rol oynadığı tespit edilmiştir. Bireyin algılarının medya yoluyla şekillenmesi denildiğinde de temsil kavramı önem kazanmaktadır.

Medya düşüncelerimizi, imajları, dünyaya bakışımızı ve değerlerimizi şekillendirmemize etki etmektedir. Günümüz dünyasında toplumsal gerçekliğin üretiminde ve tüketiminde medyanın oluşturduğu temsillerin varlığı kaçınılmazdır. Medya temsilleri üzerinden hangi değer ve inançlar kümesinin sunulduğuna, hangi sosyal gruplar üzerinden anlam üretildiğine, kitlelere nelerin normal nelerin sapkın tutum olarak gösterildiğine ilişkin araştırma soruları iletişim çalışmalarının temel çalışma konularından biridir.

Temsil ile ilgili çalışmalarda ideoloji kavramı da önemli bir yer tutmaktadır. İdeoloji, temsiller yoluyla sunmak istediği gerçekliği kitlelere kabul ettirmektedir. Bu çalışmada özellikle cinsiyetçi ideolojinin temsiller yoluyla ürettiği gerçekler üzerine durulmaktadır.

Yaşadığımız toplumsal gerçekliği yorumlayabilme ve dünyayı anlamlandırma aşamasında önemli bir yere sahip olan medya, modern yaşamın vazgeçilmezi haline dönüşmüştür. Böylelikle medya, günümüz toplumlarında zihinsel inşa sürecinin oluşmasında ayrılmaz bir bileşen haline gelmiştir.

Zihinsel inşa sürecinde radyo, televizyon ve gazeteler gibi geleneksel medya araçlarının yanı sıra yeni medya olarak adlandırılan internet ortamı da etkili olmaktadır. Geleneksel medyadan farklı olarak yeni medya, etkileşimsellik, multimedya biçemselliği, hipermetinsel yapısı ve dijital kodlama özelliği ile çok sayıda enformasyonun toplanması, saklanması, gerektiğinde dolaşıma sokulmasına olanak sağlamaktadır. Günümüzde yeni medyanın en önemli enformasyon araçlarından biri internet gazeteleridir.

Temsilin bir inşa süreci olduğu ön kabulüyle hareket eden bu çalışmanın temel amacı, internet gazetelerinde kullanılan fotoğraflardaki kadın ve erkek temsillerinin, cinsiyetçi ideolojiyle uyumlu bir kadın ve erkek kimliğinin inşa edilmesine katkıda bulunacak nitelikte olup olmadığının saptanmasıdır. Bu araştırma yoluyla, genel olarak medyada, özel olarak da internet gazetelerinde sunulan toplumsal cinsiyet temsillerinin kadınların ve erkeklerin kimliklendirme sürecindeki rolüne ve aynı zamanda da ataerkil sistemin işleyiş mekanizmasına yönelik farkındalıkların ortaya çıkarılması amaçlanmaktadır. $\mathrm{Bu}$ araştırmanın hedeflerinden biri de medyadaki cinsiyetçi politika ve uygulamaların sonuçlarını görünür kılan bilimsel bilgi üretimine katkıda bulunmaktır.

$\mathrm{Bu}$ araştırmadan elde edilecek bulgular temelinde, internet gazetelerinin cinsiyet kimliği özelliklerinin oluşumunu etkileme ve bu yolla ataerkil sistemin devamlıı̆ına katkıda bulunma yönü vurgulanmaktadır. 


\section{Literatür Taraması}

\subsection{Temsil Kavramı}

İletişim çalışmalarında kullanıldığı haliyle temsil kavramı sosyal grupların, farklı alt kültür, meslek, yaş, sosyal sınıf ve mekanların medyada gösterilme şeklini ve bu gösterilme şeklinin izleyiciler tarafından nasıl yorumlandığını anlatmaktadır (Price, 1998: 43). Başka bir deyişle, temsil kavramıyla insanların kile iletişim araçlarında kendilerine ve başkalarına nasıl sunulduğu sorunsallaştırılmaktadır.

Hall'a göre temsil, belli bir kültüre sahip bireyler arasındaki ortak anlamların, bu anlamların üretiminin ve değiş tokuş sürecinin temel noktasıdır. (2003: 16). Hall, ayrıca temsil ve anlam ilişkisine farklı bir bakış açısıyla yaklaşmıştır. Ona göre temsil, anlamı inşa eden bir yapı olarak değerlendirilmelidir.

Edward Said'e göre ise temsil kavramı tarihsel, kültürel, siyasal bağlamla iç içe geçmiş durumdadır (1999: 285). Temsilin gerçek ve doğru olanla ilişkisini sorgulayan Said, temsilin "gene bir temsil" olan gerçeğin ya da doğrunun yanında pek çok şeyle inşa edildiğini vurgular.

Medya araştırmalarının gündemine ilk kez 70'li yıllarda giren temsil kavramı, kültüre ilişkin bütün temsillerin politik olduğuna dair tartışmaların doğmasına neden olmuştur. 1960'lı yıllarda ortaya çıkan feminist, siyahi ve eşcinsel hareketler kendilerinin medyadaki temsil ediliş biçimlerine de karşı çıkarak temsillerin tartışmaya açıldığı süreci başlatmış oldular. Bu süreçte, yapılan araştırmalar sonucunda medyada üretilen temsillerin belli grupları olumlu, başka bazı grupları ise olumsuz bir şekilde topluma sunduğu, böylece egemen sosyal grupların çıkarlarına hizmet ettiği ortaya çıkarılmıştır. "Bu doğrultuda medyadaki rol modelleri, toplumsal cinsiyet kimliğini, normları, değerleri, uygun olan ve olmayan davranışları belirleyen etkili bir güç olarak yorumlanmıştır" (Durham ve Kellner, 2006: 32-33).

Temsil kavramını açıklarken önemli noktalardan biri de anlamlar üzerine olan etkisidir. "Kitle iletişim araçları, temsil sistemlerine yalnızca gerçek dünyayı kodlayarak veya yansıtarak değil, aynı zamanda anlam üreterek ve anlamların değişimine imkân tanıyarak katılmaktadır" (Çelenk, 2005: 81). Hall'un ifadesiyle, medya anlamlandırma failidir. Gerçekliği yalnızca yeniden üretmez, aynı zamanda tanımlar. Medyada 'gerçek' denilen şeyin seçilmiş tanımları temsil edilir (1998: 88). Anlam ve gerçek ilişkisi üzerine Stephane Greco Larson da medyanın, gerçekliği dünyanın işleyişine ilişkin belli anlam ve yorumları destekleyecek bir şekilde yeniden sunduğunu söylemiştir. Larson'a göre, bu temsiller, statükoyu, yani belli inanç, yapı ve eşitsizlikleri tutarlı olarak destekleyecek şekilde seçilmekte ve yapılandırılmaktadır (2006: 2). Yapılandırılan anlamların en somut örnekleri medya içerikleri yoluyla kitlelere ulaşmaktadır.

Medyada belli tipte insanlar sürekli belli rollerde gösterilmekte, bu şekilde medya içeriklerini takip eden insanlara toplum hakkında belli kalıplar sunulmaktadır. Bu kalıplar ise, insanları hem başkalarını hem de kendilerini belli şekillerde görmeye yönlendirmekte, kime ve neye değer vereceklerini, kime ve neye karşı çıkacaklarını öğretmekte, dolayısıyla belli görme biçimleri inşa etmektedir.

Temsillerin belli görme biçimleri inşa ettiği iddiası, temsilin gerçeklikle ilişkisini sorgulamayı gerektirmektedir. Lawrence Grossberg ve diğerleri, "yeniden sunum" (re-presentation) demek 
olan temsil (representation) kelimesinin, orijinal bir şeyi alıp, dolayımlayıp "yeniden göstermek" anlamına geldiğini söylemektedir. Fakat bu süreç, orijinalin gerçekliğini neredeyse zorunlu olarak değiştirmektedir. Temsil, gerçeklik hakkında bir iddiada bulunmayı içermektedir; fakat gerçekliğin aynısı değildir. Diğer taraftan, yalnızca hayali bir dünyayı gerçekçi olarak inşa etme meselesi de değildir. "Temsil sürecinde, metnin oluşturucusu, izleyiciyi metnin yarattığı evrene çekmek suretiyle metnin izleyici üzerindeki etkisini ve yaşattığı deneyimi maksimum seviyeye çıkarmaya çalışmaktadır" (Grossberg, 2006: 185). Grossberg, bu noktada temsil ile yaratılan bir gerçeklik evrenine vurgu yapmaktadır. Temsil ile yaratılan bu gerçeklik evreni izleyiciye cazip kılınmalıdır.

\subsection{Geleneksel Medya Araçlarında Toplumsal Cinsiyet Kimliklerinin Temsili}

Medyada üretilen içeriklerde, bazen açık seçik olarak bazen de örtük olarak kitlelere verilen toplumsal cinsiyet mesajları, toplumdaki erkek ve kadın bireyleri belli kalıplar içine yerleştirerek ister kadın olsun ister erkek bireyin kendine verilen roller doğrultusunda yaşamasını beklemektedir.

Aktarılan mesajlarda genellikle erkekler zeki, baskın karakterli, bağımsız ve başarılıyken kadınlar anne, eş, erkeğe destek olan erkeğine bağımlı görünümlerle karşımıza çıkmaktadırlar.

"Son dönemlerde bu imajların tam tersi olan mesajlar aktarılmakta olsa da kadınların bu görünümlerden sıyrııp zeki, başarılı olarak göründükleri filmler hala bunun tam tersini ortaya koyan "aptal sarışın" filmleri kadar çok sayıda değildir. Böylelikle medya tarafından yaratılan kadına yönelik imajlarla (ev hanımı, anne, eş ve tüketici vs.) toplumda kadınların nasıl bir kimlik ile var olması gerektiği ortaya konulmaktadır. Kadına biçilen rollerin tamamı, toplumun üstüne adeta sağanak şeklinde boşaltılmıştır, boşaltılmaktadır” (Tanrıöver, 2013: 56).

Medya içerikleri, çoğunlukla kadının bağımlı konumuna vurgu yaparken onların ev ve aileye ilişkin rollerini yüceltmektedir. Kadınlık çoğu kez duygusallık, uyumluluk, evcimenlik ve sağduyu ile yakıştırılırken bu özelliklere sahip kadınlar kahramanlaştırılmakta, bunun tersi olarak sunulan kadın imajı ise bağımsız, duyarsız, başına buyruk ve bencil şekilde tanımlanmaktadır.

Medya içeriklerinde üretilen temsillerin çizdiği ideal kadın portresi uyumlu, hırsı olmayan, hanımefendi ve yumuşak karakterlidir. İdeal erkek tipine baktığımızda ise zeki, kararlı, hırslı, bağımsız ve iddialıdır. Verilen mesajlarda erkeğin etken konumu pekiştirilirken kadın ise edilgen bir kimlikle konumlandırılır.

Medya, birbirine karışmış söylemlerin temsil edildiği, aynı zamanda bu temsillerin sürekli tekrar edildiği disiplinler arası bir alandır. Bu vasfıyla medya, toplumsal cinsiyete ilişkin rollerin inşasında önemli bir etkiye sahiptir. Medya tüm araçlarıyla birlikte toplumsal cinsiyet rollerini sadece yansıtmakla kalmaz aynı zamanda döneme ait sosyal, siyasal ve ekonomi ile bağlantılı olarak yeni bir anlayışın yaratılmasının da öncüllerinden biri olur.

Medya araçları içerisinde belki de en çok etkiye sahip araç televizyondur. Görselliğin yanında duygusallığa da hitap etmesi, geniş kitlelere ulaşabilmesi ve eğlenceli olması bakımından televizyon uzun zamandır diğer medya araçlarına oranla daha gözde bir medya aracıdır. "Dolayısıyla, medya araçları içerisinde, toplumsal cinsiyet mesajlarının hedefe ulaşmasında ve pekiştirilmesinde birincil önemli görev televizyonundur. Eğer bugünkü, televizyon izleme eğilimleri sürerse, bugün doğan ortalama bir çocuk on sekiz yaşına geldiğinde zamanının büyük bölümünü, uyuma dışındaki bütün etkinliklerden daha çok televizyon izlemeye ayıracaktır" (Giddens, 2000: 391).

Televizyon yapımlarında kadın görünümlerinin çocuklarının annesi, fedakâr eş, hanımefendi gibi 
konumlarla vurgulanması toplumda var olan geleneksel kadın kimliğinin pekiştirilmesi sürecini hızlandırmaktadır. Kadının görünümüne ilişkin dikkat edilmesi gereken bir diğer durum ise kadının cinsel bir obje olarak yansıtılmasıdır. Kadının bu görünümünde cinsel kimlik öne çıkarılarak kadına yönelik olumsuz bir algı oluşturulmaktadır. Bu aşamada kadının medyadaki görünürlüğünün yoğunlaştığı söylenebilir. "Kadınlar medyada cinselliklerinin dışında önemli bir değerlendirmeye alınmadıkları gibi, cinselliklerini kendilerinin yaptığı tanımlama ile kimliklerinin olağan bir parçası haline getirerek var olamamaktadırlar" (Saktanber, 1995: 215). Saktanber'in de dile getirdiği gibi genel anlamda televizyon yapımlarında kadın kimliğinin cinsel anlamda daha ön planda tutulduğu söylenebilir.

Televizyon, kitleleri eğlendirmenin yanı sıra şekillendirmek üzere de planlanmıştır ve bu amaca yönelik olarak televizyon yayınları yapılmaktadır. Televizyon vasıtasıyla bazı yaşam tarzlarını izleyiciye kabul ettirmek ve bu izleyici topluluğunu yönlendirmek, istediğini yaptırmak kolayca mümkün olmaktadır. Bu durumun başarıyla uygulandığı toplumsal kesim daha çok kadınlardır. Günümüzde medya araçları için üretilen içerikler aracılığıyla "kadın”ın cinselliği ön plana çıkarılarak, kadının kimliği, belli sınırlarla çizilmiştir.

Kuruoğlu'na göre TV dizilerinde kadın; evinde mükemmel bir eş, çocuklarını hiç inmal etmeyen bir anne, ekonomik özgürlüğe sahip, işinde kariyer yapmış başarılı bir iş kadınıdır. Spor yapar, kitap okur, sosyal aktivitelere de zaman ayırır, hatta ev işlerinde yardımcı kadına bile yardım eder (2000).

Medya araçlarında kadınların yer alış biçimleri hangi program, yazı, araç, görüntü olursa olsun şu ana başlıklar altında toplanabilir (Büyükbaykal, 2011: 42).

1. Şiddete maruz kalan kadın

2. Zavallı, korunmaya muhtaç kadın

3. Cinsel obje olarak kadın

4. İyi eş

5. İyi anne

6. Kötü eş

7. Kötü anne

8. Yuva yıkan ahlaksız kadın

9. Tüketen kadın

10. Tükettiren kadın

Tanrı̈̈ver, Türk televizyon dizileri üzerine yaptığı bir çalışmaya dayanarak, 1990'ların ortalarından itibaren kadın karakterlerin özelliklerinde bazı değişiklikler saptandığını söylemiştir. Bunlardan en önemlileri, genç kızların annelerinden daha özgür, daha çok meslek ve fikir sahibi olarak sunulmalarıdır (2007: 63).

O’Bryant ve Corder-Bolz'un 1978 yılında yapmış olduğu araştırmalar ise televizyonun toplumsal cinsiyet kimliklerinin oluşmasındaki etkisine dikkat çekmektedir. Bu araştırmalara göre televizyon, erkeklerin ve kızların toplumsal cinsiyet kimliklerinin oluşumunda anaokulu dönemlerinden itibaren 
etkili olmaktadır. Bem'e göre de birey, küçük yaşlardan itibaren televizyonun etkisiyle toplumsal cinsiyet kimliğini yavaş yavaş oluşturmaya başlar. Bireyde oluşmaya başlayan toplumsal cinsiyet kimliği hem kendi ile ilgili algılarını etkiler hem de içinde bulunduğu toplumsal çevreyle ilgili algılarını etkiler. (Akt. Sabuncuoğlu, 2006: 122-123).

Medyada özellikle gazetelerde cinsiyet kimliklerinin sunumuna ilişkin araştırmaların yaklaşık 40 yıllık bir geçmişi vardır. Gazetelerdeki cinsiyet kimliklerine yoğunlaşan ilk çalışmalardan biri Gaye Tuchman, Arlene Kaplan Daniels ve James Benet tarafından yazılan "Hearth and Home" (1978) adlı makaledir. Bu çalışma Byerly ve Ross'a göre teorik ve gözlemsel yapısıyla gazetelerde kadının temsilinin sorunlu durumunu ele alan ilk çalışmalar arasındadır. Bu makale, kadının sadece medyadaki rutin eksikliğini ya da sembolik yok oluşunu irdelemez, ayrıca kadın stereotiplerinin nasıl oluştuğu üzerine de görüşler sunar (Akt. Kuruoğlu ve Akçora, 2017: 8).

1990'lı yıllarda medyada cinsiyet kimliklerine ilişkin daha kapsamlı çalışmalar yapılmaya başlanmıştır. Bu çalışmalardan biri Nancy Signorelli tarafından 1997 yılında yapılan "Reflections of Girls in the Media" adlı çalışmadır. 10-17 yaş arası kız çocuklar üzerine yapılan bu araştırma da televizyon, gazete ve dergi içeriklerinin kız çocukları tarafından nasıl anlamlandırıldığı araştırılmıştır. Araştırma sonuçlarına göre söz konusu içerikler kız çocuklarına anne, eş, sevgili gibi kadına ait geleneksel rolleri sunmaktadır.

Bir diğer önemli araştırma Cory Armstrong tarafından 2006 yılında yapılan "Writing About Women: An Examination of How Content for Women Is Determined in Newspapers" adlı çalışmadır. Armstrong bu çalışmada Amerika Birleşik Devletleri'ndeki en yüksek tiraja ulaşan gazeteleri örneklemine dahil ederek gazetelerde kadın ve erkek görünürlüğünü araştırmıştır. Araştırmanın sonuçlarına göre Amerika Birleşik Devletlerindeki gazetelerde erkeklerin görünürlüğü daha fazladır. Aynı zamanda haberi üreten muhabirlerde de erkeklerin sayıca fazlalığı görülmektedir.

Küresel Medya İzleme Projesi (The Global Media Monitoring Project- GMMP), 2015 yılında 114 ülkedeki gönüllü temsilciler vasıtasıyla gazeteler ve haber siteleri üzerinde cinsiyet kimliklerinin görünürlüğü üzerine bir araştırma gerçekleştirmiştir. Araştırmada 2015 yılı itibariyle gazete haberlerinde kadınların görünürlük yüzdesi \%26, erkeklerin ise $\% 74$ olmuştur. Haber sitelerinde ve internet gazetelerinde ise bu oran kadınlar için \%28 erkekler içinse \%72 olmuştur.

Feyza Akınerdem tarafından 2016 yılında "Türkiye Medyasında Kadınların Temsili: Gazete ve İnternet Haberciliği Raporu” adlı çalışmada, kadınların haberlerde sunum biçimleri değerlendirilmiştir. $\mathrm{Bu}$ araştırmanın sonuçlarına göre, medya içeriğinde ve söyleminde yüksek oranda cinsiyetçi bir ayrımcılık vardır. Akınerdem'e göre, araştırmanın bir diğer sonucu ise kadınların medyada her zaman edilgen bir nesne konumunda sunulmadığıdır (2016: 40). Haber anlatısında kadının suçluluğunun ve görünürlüğünün yarattığı tehlikeye vurgu yapılmıştır. Bu vurguya bağlı olarak kadın toplumsal geleneğin ve kuralların ihlalinde birincil sorumlu olarak gösterilmektedir.

Haber ve nesnellik ilişkisine yönelik yapılan araştırmalarda değinildiği gibi, herhangi bir konuya ilişkin yapılan haberlerde söylemin nasıl yapılandırıldığı kadar söylenmeyen ya da yer verilmeyen şeyler de haber-nesnellik ilişkisini analiz ederken önemli bir kriter olarak alınmaktadır. Aynı durum medyanın kadına yönelik tutumu için de söylenebilir. Medyanın gösterdiği kadın imajındaki en 
dikkat çeken özelliklerden biri; bize gösterdikleri değil göstermedikleridir. Kadın haberlerde ev, aşk ve cinsellik ile ilişkilendiriliyorsa kadının ilişkilendirilmediği şeyler para, iş ve siyasettir. Medya içeriklerine baktığımızda kadının konumlandırılması bu yaklaşımı doğrular niteliktedir.

\section{2. İnternet Gazetelerinde Toplumsal Cinsiyet Kimliklerinin Sunumuna Ilișkin Araștırma}

\subsection{Araștırma Modeli}

\subsubsection{Yöntem}

"Yeni Medya ve Temsil: İnternet Gazeteciliğinde Toplumsal Cinsiyet Kimliklerinin Sunumu” başlıklı çalışma kapsamında, internet gazetelerinde yer alan kadın ve erkek fotoğraflarında toplumsal cinsiyet rolleriyle uyumlu ve cinsiyetçi ideolojiyi güçlendiren bir kadın ve erkek kimliğinin inşa edilip edilmediği çözümlenmiştir.

Cinsiyet kimliklerinin internet gazetelerinde nasıl temsil edildiğine, dolayısıyla internet gazetelerinde kadınlara ve erkeklere yönelik nasıl bir temsil politikası izlendiğine ilişkin temel soruları cevaplandırmak üzere, seçilen çözümleme birimine aşağıdaki araştırma soruları (AS) yöneltilmiştir:

AS 1: İncelenen internet gazetelerinde kadın- erkek görünürlüğü arasında farklıık var mıdır?

AS2: İncelenen internet gazetelerinde hangi yaş ve meslek grubundaki kadınlar ve erkekler daha görünür kılınmaktadır?

AS3: Incelenen internet gazetelerinde kadınlar ve erkekler hangi rollerde temsil edilmektedir?

AS4: İncelenen internet gazetelerinde kadınlara ve erkekler hangi tür haberlerde daha çok yer verilmektedir?

AS5: İncelenen internet gazetelerinde görüntülenen kadınların ve erkeklerin giyiniklik derecesi nedir?

Belirlenen araştırma sorularına cevap bulmak için nitel içerik çözümlemesi yöntemi uygulanmıştır. Weber, içerik çözümlemesini metinden geçerli çıkarımlar yapmak için kullanılan bir araştırma tekniği olarak tanımlamıştır (1990: 9). Neuendorf'a göre ise içerik çözümlemesi; objektiflik, intersubjektivite, önsel tasarım, güvenirlilik, geçerlilik, genelleştirilebilirlik, yenilenebilirlik ve hipotez testleri gibi birtakım bilimsel yöntemlere dayalı olarak mesajların kantitatif analizidir (2002: 10).

Özellikle son yıllarda sosyal bilimler alanında kullanılacak nicel ve nitel yöntemler üzerine farklı düşünceler ortaya çıkmıştır. "Geçmiş yıllarda gerek kitle iletişim alanındaki gerekse diğer alanlardaki araştırmalarda nicel ve nitel yöntemlerden hangisinin tercih edilmesi gerektiği konusunda belli bir bölünme yaşanmışsa da bugün birçok araştırmacı herhangi bir olgunun anlaşılabilmesi için her iki yöntemin de önemli olduğu noktasına gelmiş bulunmaktadır. Dolayısıyla, artık her iki yöntemin de kullanılması önerilmektedir" (Wimmer ve Dominick, 2011: 49). Diğer taraftan, Satu Elo ve Helvi Kyngash, araştırılan olguya ilişkin önceden yapılmış çalışmaların bulunmadığı veya mevcut bilginin dağınık olduğu durumlar için nitel içerik çözümlemesini, önceden mevcut bir kuramı farklı bir durum için test etmek veya aynı kategorileri farklı zaman dilimleri açısından karşılaşıımak için ise nicel içerik çözümlemesini önermiştir (2008: 113). Bu araştırmanın konusunu oluşturan internet gazetelerinde cinsiyet kimliklerinin inşasına yönelik bir çalışmanın bulunmaması, konuyla ilgili 
mevcut bilgilerin ise dağınık durumda bulunması nedeniyle, bu çalışmada nitel içerik çözümlemesi yöntemi benimsenmiştir.

Çalışmanın evrenini Türkiye`de yayınlanan bütün internet gazeteleri oluşturmuştur. İncelenen verilerin seçilmesinde öncelikle sistematik örnekleme yöntemi uygulanmıştır. "Sistematik örnekleme yöntemi, evrenden belli ölçütler temelinde ve sistematik bir yöntemle örneklem oluşturulmasını temel almaktadır" (Yıldırım ve Şimşek, 2008: 104). Krippendorff, sistematik örneklemin, yayın, gazete, televizyon dizisi, kişiler arası iletişim gibi düzenli, sürekli veya tekrarlamalı olarak oluşan metinlerin incelenmesinde avantaj sağladığını söylemiştir (2004: 115). Sistematik örnekleme daha çok nicel araştırmalarda kullanılan bir yöntem olmakla birlikte, Ali Yıldırım ve Hasan Şimşek, döküman incelemesi temelindeki nitel çözümlemelerde de sistematik örneklemenin kullanılabileceğini ifade etmiştir (2008: 198).

Bu çalışma kapsamında sistematik yöntemle seçilen örneklemin belirlenmesinde kullanılan ölçüt internet gazetelerinin tıklanma sayısı olup, tıklanma bilgileri internet reyting verilerini yayınlayan Alexa adlı siteden alınmıştır. Bu doğrultuda, Alexa adlı sitenin verdiği bilgilere göre, 31 Mayıs 2017 tarihinde Türkiye'de yayınlanan internet gazetelerinden tıklanma sayısı en fazla olan ilk üç internet sitesi belirlenmiştir. Bu siteler, tıklanma sayısı sırasıyla "milliyet.com.tr", "hurriyet.com.tr" ve "sabah. com.tr" dir. Bu gazetelerin 01 Haziran 2017 ile 15 Haziran 2017 tarihleri arasındaki yayınlarının arşivlenmiş versiyonları araştırmanın örneklemi olarak kabul edilmiştir.

$\mathrm{Bu}$ araştırma üç internet gazetesinin 15 gün boyunca yaptığı yayınlarla sınırlıdır. Araştırmada internet gazetelerinin gün boyunca sürekli güncellenmesi nedeniyle, ilgili gazetelerin incelenen güne ait arşiv sayfaları esas alınmıştır. Bu yolla, incelenen tüm gazetelere uygulanabilecek bir sabitleme kriteri kullanılmıştır.

Daha önce yapılmış benzer çalışmalardan (Pillay, 2008; Mediz, 2008; GMMP, 2015) faydalanılarak altı farklı içerik kategorisi belirlenmiştir. Bu kategoriler aşağıdaki tablolarda gösterilmiştir.

Tablo 1: Kadın ve Erkeğin Görünürlüğüne Illişkin Kategori Tablosu

\begin{tabular}{|l|l|l|}
\hline \multicolumn{2}{|l|}{ KADININ/ERKEĞiN GÖRÜNÜRLÜĞÜ } & \multirow{3}{*}{ KAYNAK } \\
\cline { 1 - 2 } & Kadın & \\
\cline { 2 - 3 } & Erkek & \\
\hline
\end{tabular}

Tablo 2: Kadın ve Erkeğin Yaşına İlişkin Kategori Tablosu

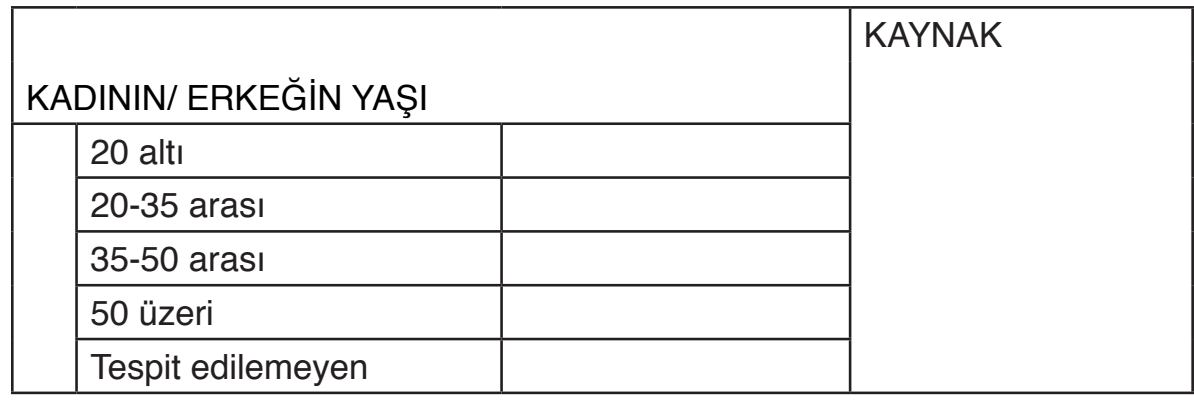


Tablo 3: Kadın ve Erkeğin Mesleğine İlişkin Kategori Tablosu

\begin{tabular}{|c|c|c|}
\hline \multicolumn{2}{|c|}{ KADININ/ ERKEĞiN MESLEĞi } & KAYNAK \\
\hline Üst Düzey Yönetici & $\begin{array}{l}\text { Ticari işletmelerde yüksek seviyede } \\
\text { beceri (vasıf ve deneyim), olgunluk } \\
\text { ve yetki gerektiren bir konum. } \\
\text { Örneğin ticari bir işletmenin yönetim } \\
\text { kurulu başkanı ve diğer üst düzey } \\
\text { yöneticileri. }\end{array}$ & \multirow[t]{7}{*}{$\begin{array}{l}\text { Pillay, } \\
2008\end{array}$} \\
\hline $\begin{array}{l}\text { Yüksek Vasıflı } \\
\text { Meslek Sahibi }\end{array}$ & $\begin{array}{l}\text { Yüksek vasıf ve beceri düzeyi } \\
\text { gerektiren, üst düzey yöneticinin } \\
\text { bir altındaki meslekler. Örneğin, } \\
\text { müdür, öğretim görevlisi, doktor ve } \\
\text { avukatlar. }\end{array}$ & \\
\hline $\begin{array}{l}\text { Yarı-Vasıflı Meslek } \\
\text { Sahibi: }\end{array}$ & $\begin{array}{l}\text { Yüksek düzeyde vasıflı olmayan } \\
\text { meslekler. Örneğin, satış görevlileri, } \\
\text { teknisyenler ve yönetici asistanları. }\end{array}$ & \\
\hline $\begin{array}{l}\text { Eğlence Sektöründe } \\
\text { Görevli }\end{array}$ & $\begin{array}{l}\text { Eğlence sektöründe yer alan } \\
\text { manken, magazin figürü, oyuncu ve } \\
\text { şarkıcılar. }\end{array}$ & \\
\hline Profesyonel Sporcu & $\begin{array}{l}\text { Spor faaliyetlerine profesyonel } \\
\text { olarak ve müsabaka seviyesinde } \\
\text { katılan yüksek düzeyde vasıflı } \\
\text { kişiler. }\end{array}$ & \\
\hline Kamu Görevlisi & $\begin{array}{l}\text { Devlet kurum ve kuruluşlarında } \\
\text { görevli kişi. }\end{array}$ & \\
\hline Diğer & & \\
\hline
\end{tabular}

Tablo 4: Kadın ve Erkeğin Temsil Biçimine İlişkin Kategori Tablosu

\begin{tabular}{|c|c|c|}
\hline $\begin{array}{l}\text { KADININ/ERKEĞiN } \\
\text { TEMSiL BiçiMi }\end{array}$ & KAYNAK & \\
\hline Doğal-Eşit Varlık & $\begin{array}{l}\text { Kadınların ve erkeklerin, hayatın herhangi } \\
\text { bir alanında birbirlerine eşit biçimde "doğal" } \\
\text { olarak temsil edildiği durum. }\end{array}$ & \multirow[t]{6}{*}{$\begin{array}{l}\text { Mediz, } \\
2008\end{array}$} \\
\hline Eş, Anne/Baba & $\begin{array}{l}\text { Kadınların ve erkeklerin salt eş ya da } \\
\text { annelik/babalık konumunun altını çizen } \\
\text { içerikler }\end{array}$ & \\
\hline $\begin{array}{l}\text { Üçüncü Sayfa- } \\
\text { Magazin Nesnesi }\end{array}$ & $\begin{array}{l}\text { Kadınların ve erkeklerin, genelde "3. sayfa" } \\
\text { olarak tanımlanan haber türleri kapsamında } \\
\text { cani, suçlu ya da tersine kurban olarak } \\
\text { yer aldığı haberler ve özellikle gösteri } \\
\text { dünyasındaki yıldız kadınların/erkeklerin aşk } \\
\text { ilişkileri, giyim-kuşamları, gezdikleri yerler } \\
\text { gibi içerikler. }\end{array}$ & \\
\hline $\begin{array}{l}\text { Cinsel Nesne- Haz } \\
\text { Nesnesi }\end{array}$ & $\begin{array}{l}\text { Haber ya da içerikle doğrudan ilişkisi } \\
\text { olmadığı halde kadınların/erkeklerin } \\
\text { bedenlerini/cinselliklerini ön plana çıkaran } \\
\text { içerikler }\end{array}$ & \\
\hline Örgüt-Eylem Öznesi & $\begin{array}{l}\text { Kadınların veya erkeklerin herhangi bir } \\
\text { eyleme (toplumsal, siyasal, kültürel) } \\
\text { doğrudan katıır biçimde ya da belli bir örgüte } \\
\text { dahil olarak sunuldukları içerikler. }\end{array}$ & \\
\hline Araçsal Varlık & $\begin{array}{l}\text { İçerikle doğrudan ilgili olmadığı durumlarda } \\
\text { kadınların veya erkeklerin (gündelik deyimle) } \\
\text { "konu mankeni” biçiminde temsil edildiği } \\
\text { durumlar. }\end{array}$ & \\
\hline Diğer & & \\
\hline
\end{tabular}


Tablo 5: Kadın ve Erkeğin Görüntülendiği Haberin Niteliğine Illişkin Kategori Tablosu

\begin{tabular}{|c|c|}
\hline $\begin{array}{l}\text { KADININ/ERKEĞiN GÖRÜNTÜLENDIĞi } \\
\text { HABERIN NITELIĞi }\end{array}$ & KAYNAK \\
\hline Bilim ve Sağlık & \multirow[t]{8}{*}{ GMMP, 2015} \\
\hline Sosyal ve Hukuk & \\
\hline $\begin{array}{l}\text { Magazin, Sanat ve } \\
\text { Medya }\end{array}$ & \\
\hline Suç ve Şiddet & \\
\hline Ekonomi & \\
\hline Siyaset ve Hükümet & \\
\hline Kız Çocuğu & \\
\hline Diğer Konular & \\
\hline
\end{tabular}

\subsubsection{Veri Toplama Teknikleri}

Araştırma kapsamında incelenen internet gazetelerinin, 01 Haziran 2017 ile 15 Haziran 2017 tarihleri arasında yayınlanan ana sayfaları dikkate alınmışıı. Bu durumun nedeni gazetelerin en fazla görünürlüğe sahip sayfalarının "gazetenin vitrini" olarak nitelendirilen ana sayfaları olmasıdır. Araştırmanın çözümleme birimi olarak, internet gazetelerinin ana sayfalarında yer alan fotoğraflar seçilmiştir. Fotoğrafların seçilme nedeni, Gillian Rose'un ifade ettiği üzere, imgelerin tek başına toplumu etkileme gücüne sahip olmasıdır (2002: 10). Söz konusu gazetelerde kullanılan kadın ve erkek fotoğraflarının oluşturduğu etkinin, genel olarak toplumun cinsiyet algısına bakışını dolayısıyla kimliklendirme süreçlerini önemli ölçüde etkilediği kabul edilmiştir.

Araştırma örneklemi, Barney G. Glaser ve Anselm L. Strauss'un "kuramsal doyum" (2006: 61) noktası olarak adlandırdığı, verilerin kendini tekrar edip etmediği dikkate alınarak belirlenmiş̧ir. Bu temelde, 15 gün boyunca yayınlanan internet gazeteleri araştırma kategorileri temelinde taranmış, bu süre boyunca verilerin kendini tekrar etmesi nedeniyle, örneklemin kuramsal doyum noktasına ulaşıı̆ı düşünülmüştür. Araştırma kapsamında incelenen toplam kadın fotoğrafı sayısı bin 318'dir. Erkek fotoğrafı sayısı ise 2 bin 10'dur.

\subsubsection{Veri Çözümleme Yöntemi}

Bu çalışma bağlamında çözümlemenin yanlıı̆̆ını azaltmak, kullanılan kategorilerin ağırlığını tespit etmek, çözümlemeye konu olan internet gazeteleri arasında karşılaştırma yapabilmek amacıyla, ilk aşamada veriler sayılara indirgenmiş ve basit yüzde hesapları uygulanmıştır. Bu amaçla, incelenen gazetelerdeki kadın ve erkek fotoğrafları görsel metin olarak kabul edilmiş, fotoğraflar üzerinden bir kodlama işlemi yapılmıştır. "Kodlama, veriler arasında yer alan anlamlı bölümlere isim verilmesi sürecidir" (Yıldırım ve Şimşek, 2008: 227). Bu aşamada verilerden elde edilen kavramlardan yararlanılarak yapılan kodlama yöntemi kullanılmışıิır.

Kodlamayla elde edilen veriler cinsiyet temsiline ilişkin kategorilere yerleştirilmiştir. Belirlenen kategorilere giren fotoğrafların kullanım sıklıkları (f) ve yüzdeleri (\%) hesaplanmıştır. 


\subsubsection{Geçerlilik ve Güvenirlilik Așaması}

Bu aşamada araştırmanın geçerlik ve güvenirlik çalışması yapılmışıı. Araştırmanın sonuçlarının inandırıcılığını sağlama noktasında geçerlik ve güvenirlik önem arz etmektedir. "Araştırma boyunca toplanan verinin nasıl elde edildiğinin açıklanması geçerlik ve güvenirliğin sağlanmasında gerekli bir husustur" (Gökçe, 2001: 18). Araştırmayla elde edilen bulguların tutarılıı̆ını test etmek için kategorilerin kendi tutarılıkları ve diğer kavramsal kategorilerin kendi tutarlılıkları ile diğer kavramsal kategorilerle olan tutarlılı̆ı denetlenip anlamlı bir bütün oluşturup oluşturmadığı değerlendirilmiştir. Bunun için her kavramsal kategorinin altına gelecek kodun, o kavramsal kategori ile maksimum düzeyde ilişkili olmasına dikkat edilmiştir. Ardından araştırmanın amacına uygun olarak seçilen kategoriler uzman bir öğretim üyesine verilerek incelettirilmiştir.

Güvenirliğin sağlanması için kavramsal kategorilerle verilen kodların söz konusu kavramsal kategoriyi temsil edip etmediğini denetlemek amacıyla alandan bir uzmana başvurulmuştur. Bunun için kategori tablolarının olduğu iki ayrı liste uzmana verilmiş̧ir. Uzman tarafından yapılan eşleştirme ile araştırmacının yaptığı eşleştirme karşılaştırılmıştır. Bunun için Miles ve Huberman'ın (1994: 64), Güvenirlik = Görüş birliği/ (Görüş birliği + Görüş ayrılığı) formülü kullanılmıştır. Nitel araştırmalar için güvenirlik sonucu \%70'in üzerindeyse görüş birliğinin sağlandığı kabul edilmektedir. Bu çalışma özelinde oran \%77 olarak tespit edilmiştir.

\section{Bulgular ve Yorum}

Bu bölümde, 01.06.2017 ve 15.06.2017 tarihleri arasında yayınlanan üç internet gazetesinin (milliyet.com.tr, hurriyet.com.tr ve sabah.com.tr) bir önceki bölümde belirtilen veri toplama araçları kullanılarak taranması sonucunda elde edilen bulgular sunulmakta ve çözümlenmektedir.

Tablo 6: 01.06.2017 ile 15.06.2017 Tarihleri Arasındaki Üç İnternet Gazetesinin ana sayfasında cinsiyete göre belirlenen fotoğraf tablosu:

\begin{tabular}{|l|l|l|}
\hline $\begin{array}{l}\text { Fotoğrafta Yer Alan Aktörlerin } \\
\text { Cinsiyeti }\end{array}$ & F(Sıklık) & $\%$ \\
\hline Kadın Fotoğrafları & 1318 & $\% 39.6$ \\
\hline Erkek Fotoğrafları & 2010 & $\% 60.4$ \\
\hline Toplam & 3328 & 100 \\
\hline
\end{tabular}

\section{1. İnternet Gazetelerinde Kadın Temsiline İlișkin Kodlama Bulguları}

01.06.2017 ve 15.06.2017 tarihleri arasında yayınlanan üç internet gazetesinin (milliyet.com. tr, hurriyet.com.tr ve sabah.com.tr) kadın temsiline ilişkin elde edilen bulgular aşağıdaki tabloda sunulmuştur. 
Tablo 7: 01.06.2017 ile 15.06.2017 Tarihleri Arasındaki Üç İnternet Gazetesinin Ana Sayfasında Kadın Temsiline İlişkin Kodlama Bulguları

\begin{tabular}{|c|c|c|c|c|c|c|c|}
\hline Kategoriler & & & & & & & \\
\hline \multirow{3}{*}{$\begin{array}{l}\text { Kadının } \\
\text { Yaşı }\end{array}$} & 20 Altı & 20-35 Arası & 35-50 Arası & 50 Üzeri & Tespit & & \\
\hline & $f=84$ & $f=815$ & $f=123$ & $f=81$ & $f=215$ & & \\
\hline & $\% 6.3$ & $\% 61.8$ & $\% 9.3$ & $\% 6.1$ & \% 16.3 & & \\
\hline \multirow[t]{3}{*}{$\begin{array}{l}\text { Kadının } \\
\text { Mesleği }\end{array}$} & $\begin{array}{c}\text { Üst } \\
\text { düzey } \\
\text { yönetici }\end{array}$ & $\begin{array}{c}\text { Yüksek } \\
\text { vasıflı } \\
\text { meslek } \\
\text { sahibi }\end{array}$ & $\begin{array}{c}\text { Yarı-vasıflı } \\
\text { meslek sahibi }\end{array}$ & Eğlence & & $\begin{array}{l}\text { Resmi } \\
\text { görevli }\end{array}$ & Diğer \\
\hline & $f=20$ & $f=10$ & $f=59$ & $\mathrm{f}=789$ & $f=11$ & $f=6$ & $f=423$ \\
\hline & $\% 1.5$ & $\% 0.7$ & $\% 4.4$ & $\% 59.8$ & $\% 0.8$ & $\% 0.4$ & $\% 32$ \\
\hline \multirow[t]{3}{*}{$\begin{array}{l}\text { Kadının } \\
\text { Temsil } \\
\text { Biçimi }\end{array}$} & $\begin{array}{l}\text { Doğal- } \\
\text { eşit } \\
\text { varlık }\end{array}$ & $\begin{array}{c}\text { Eş, anne } \\
\text { ve fedakar } \\
\text { kadın }\end{array}$ & $\begin{array}{c}\text { Üçüncü sayfa } \\
\text { - magazin } \\
\text { nesnesi }\end{array}$ & $\begin{array}{c}\text { Cinsel } \\
\text { nesne } \\
\text {-haz } \\
\text { nesnesi }\end{array}$ & $\begin{array}{l}\text { Örgüt- } \\
\text { eylem } \\
\text { öznesi }\end{array}$ & & Diğer \\
\hline & $f=239$ & $f=57$ & $f=762$ & $f=131$ & $f=5$ & $f=82$ & $f=42$ \\
\hline & $\% 18.1$ & $\% 4.3$ & $\% 57.8$ & $\% 9.9$ & $\% 0.3$ & $\% 6.2$ & $\% 3.1$ \\
\hline \multirow[t]{3}{*}{ Kadının } & $\begin{array}{l}\text { Bilim ve } \\
\text { sağlık }\end{array}$ & $\begin{array}{l}\text { Sosyal ve } \\
\text { hukuk }\end{array}$ & $\begin{array}{l}\text { Magazin, sanat } \\
\text { ve medya }\end{array}$ & $\begin{array}{l}\text { Suç ve } \\
\text { şiddet }\end{array}$ & Ekonomi & & Diğer \\
\hline & $f=108$ & $f=51$ & $\mathrm{f}=906$ & $\mathrm{f}=55$ & $f=54$ & $f=54$ & $f=90$ \\
\hline & $\% 8.1$ & $\% 3.8$ & $\% 68.7$ & $\% 4.1$ & $\% 4$ & $\% 4$ & $\% 6.8$ \\
\hline
\end{tabular}

\subsection{Internet Gazetelerinde Erkek Temsiline İlișkin Kodlama Bulguları}

01.06.2017 ve 15.06.2017 tarihleri arasında yayınlanan üç internet gazetesinin (milliyet.com. tr, hurriyet.com.tr ve sabah.com.tr) erkek temsiline ilişkin elde edilen bulgular aşağıdaki tabloda sunulmuştur.

Tablo 8: 01.06.2017 ile 15.06.2017 Tarihleri Arasındaki Üç İnternet Gazetesinin Ana Sayfasında Erkek Temsiline İlişkin Kodlama Bulguları

\begin{tabular}{|l|c|c|c|c|c|c|c|}
\hline & \multicolumn{7}{|c|}{} \\
\hline \multirow{4}{*}{$\begin{array}{l}\text { Erkeğin } \\
\text { Yaşı }\end{array}$} & 20 Altı & $\begin{array}{c}20-35 \\
\text { Arası }\end{array}$ & $\begin{array}{c}35-50 \\
\text { Arası }\end{array}$ & 50 Üzeri & Tespit & & \\
\cline { 2 - 9 } & $\mathrm{f}=216$ & $\mathrm{f}=857$ & $\mathrm{f}=400$ & $\mathrm{f}=266$ & $\mathrm{f}=271$ & & \\
\cline { 2 - 9 } & $\% 10.7$ & $\% 42.6$ & $\% 19.9$ & $\% 13.2$ & $\% 13.4$ & & \\
\hline $\begin{array}{l}\text { Erkeğin } \\
\text { Mesleği }\end{array}$ & $\begin{array}{c}\text { Üst } \\
\text { düzey }\end{array}$ & $\begin{array}{c}\text { Yüksek } \\
\text { vasıflı } \\
\text { meslek } \\
\text { sahibi }\end{array}$ & $\begin{array}{c}\text { Yarı-vasıflı } \\
\text { meslek } \\
\text { sahibi }\end{array}$ & Eğlence & & $\begin{array}{c}\text { Resmi } \\
\text { görevli }\end{array}$ & Diğer \\
\cline { 2 - 9 } & $\mathrm{f}=167$ & $\mathrm{f}=330$ & $\mathrm{f}=753$ & $\mathrm{f}=88$ & $\mathrm{f}=101$ & $\mathrm{f}=145$ & $\mathrm{f}=426$ \\
\cline { 2 - 8 } & $\% 8.3$ & $\% 16.4$ & $\% 37.4$ & $\% 4.3$ & $\% 5$ & $\% 7.2$ & $\% 21$ \\
\hline
\end{tabular}




\begin{tabular}{|l|c|c|c|c|c|c|c|}
\hline $\begin{array}{l}\text { Erkeğin } \\
\text { Temsil } \\
\text { Biçimi }\end{array}$ & $\begin{array}{c}\text { Doğal- } \\
\text { eşit } \\
\text { varlık }\end{array}$ & $\begin{array}{c}\text { Eş, } \\
\text { sevgili } \\
\text { veya } \\
\text { baba }\end{array}$ & $\begin{array}{c}\text { Üçüncü } \\
\text { sayfa - } \\
\text { magazin } \\
\text { nesnesi }\end{array}$ & $\begin{array}{c}\text { Cinsel } \\
\text { nesne } \\
\text {-haz } \\
\text { nesnesi }\end{array}$ & $\begin{array}{c}\text { Örgüt- } \\
\text { eylem } \\
\text { öznesi }\end{array}$ & Diğer \\
\cline { 2 - 8 } & $\mathrm{f}=1068$ & $\mathrm{f}=152$ & $\mathrm{f}=415$ & $\mathrm{f}=29$ & $\mathrm{f}=98$ & $\mathrm{f}=81$ & $\mathrm{f}=167$ \\
\cline { 2 - 8 } & $\% 53.1$ & $\% 7.5$ & $\% 20.6$ & $\% 1.4$ & $\% 4.8$ & $\% 4$ & $\% 8.3$ \\
\hline Erkeğin & $\begin{array}{c}\text { Bilim } \\
\text { ve } \\
\text { sağlık }\end{array}$ & $\begin{array}{c}\text { Sosyal } \\
\text { ve } \\
\text { hukuk }\end{array}$ & $\begin{array}{c}\text { Magazin, } \\
\text { sanat } \\
\text { ve medya }\end{array}$ & $\begin{array}{c}\text { Suç ve } \\
\text { şiddet }\end{array}$ & Ekonomi & Diğer \\
\cline { 2 - 9 } & $\begin{array}{c}\mathrm{f}=126 \\
\mathrm{f}=174\end{array}$ & $\mathrm{f}=375$ & $\mathrm{f}=213$ & $\mathrm{f}=345$ & $\mathrm{f}=631$ & $\mathrm{f}=146$ \\
\cline { 2 - 9 } & $\% 6.2$ & $\% 8.6$ & $\% 18.6$ & $\% 10.5$ & $\% 17.1$ & $\% 31.3$ & $\% 7.2$ \\
\hline
\end{tabular}

\subsubsection{Verilerin Değerlendirilmesi}

Bu çalışma kapsamında, internet gazetelerinde cinsiyet kimliklerinin görünürlük seviyesini, hangi cinsiyetin ne ölçüde görünür kılındığını ve nasıl görüntülendiğini tespit etmek üzere bir içerik çözümlemesi yapılmıştır. İnternet gazetelerinde ve yayınlanan kadın/erkek fotoğrafları temelinde gerçekleştirilen içerik çözümlemesinde çalışmanın yöntem kısmında belirtilen araştırma sorularına cevap aranmıştır. Çözümleme sonucunda elde edilen bulgular aşağıdaki maddeler halinde özetlenebilir:

a) İncelenen gazetelerde kadın- erkek görünürlüğü arasında farklılık var mıdır? Sorusunun yanıtlanması için yapılan taramada, çözümlenen üç internet gazetesinin tümünde kadınların görünürlüğünün yayınlanan fotoğraf sayısı olarak erkeklerden daha az olduğu tespit edilmiştir. Ancak, çözümlenen internet gazetelerinde magazin haberlerinin önemli bir yer kaplaması, özellikle milliyet.com.tr'de belli gruplardan kadın fotoğraflarının büyük boyutlu ve görünürlüğü yüksek yerlerde kullanılmasına neden olmuştur.

b) İncelenen gazetelerde hangi yaş ve meslek grubundaki kadınlar ve erkekler daha görünür kılınmaktadır? Sorusunun yanıtlanması için yaş grubu ve meslek kategorileri temelinde tarama yapılmıştır. Yaş grubu kategorisinde yapılan tarama sonucunda, internet gazetelerin tümünde 20-35 yaş arası kadınların ve erkeklerin görünürlüğünün diğer kadın/erkek gruplarından fazla olduğu tespit edilmiştir. 20-35 yaş grubunu 35-50 arası yaş grubu takip etmektedir. Ancak, internet gazetelerinde bu iki yaş grubunun görünürlük sayısı arasındaki fark, 20-35 yaş grubu lehine oldukça yüksektir. Ayrıca, 20-35 yaş arası gruptaki kadın fotoğraflarının büyük boyutlu kullanılması ve görünürlüğü yüksek yerlere konulmuş olması, bu gruptaki kadınların fotoğraflardaki görünürlük seviyesini artırmıştır. TÜíK verilerine göre ise, 2016 itibarıyla 20-35 yaş arası kadın grubu, toplam kadın nüfusunun yalnızca yüzde 25>ini oluşturmaktadır. Dolayısıyla, internet gazetelerinde daha ağırlıklı olmak üzere, her iki gazete grubunun, toplumdaki kadınların yaş dağılımı açısından çeşitliliğini yansıtmaktan uzak olduğunu söylemek mümkündür.

c) İncelenen gazetelerde kadınlar ve erkekler hangi rollerde temsil edilmektedir? Sorusunu yanıtlamak için çözümlenen gazetelerde görüntülenen kadınların ve erkeklerin meslek grupları tespit edilmeye çalışılmıştır. Çözümleme sonucunda, taranan internet gazetelerinin tümünde eğlence sektöründe 
yer alan kadınların diğer meslek gruplarındaki kadınlardan çok daha fazla sayıda görünür kılındığı tespit edilmiştir. Bu durum tarama yapılan 15 gün boyunca düzenli olarak devam etmiştir. Diğer kategorilerde olduğu gibi, bu kategoride de kullanılan fotoğrafların boyutlarına ve sayfadaki yerine ilişkin seçimlerin internet gazetelerinde "Eğlence Sektöründe Görevli” kadınların görünürlüğünü daha da artırdığı tespit edilmiştir. Eğlence sektöründe yer alan kadınların kadın nüfusu içinde yalnızca küçük bir oranı oluşturduğu göz önüne alındığında, toplumdaki kadınların meslek dağııımı açııından çeşitliliğinin internet gazetelerinde yansıtılmadığı ortaya çıkmaktadır. Erkeklerin internet gazetelerindeki meslek dağılımına bakıldığında ise üç internet gazetesinde de "Yarı Vasıfı Meslek" kategorisinde görünen erkekler ilk sırada yer almaktadır. İkinci olarak görüntülenen meslek grubu ise "Yüksek Vasıflı Meslek" kategorisidir. "Eğlence Sektöründe Görevli" kategorisinde görünen erkeklerin aynı kategorideki kadın görünürlüğüne nazaran çok az sayıda olduğu tespit edilmiştir.

d) İncelenen gazetelerde kadınlar ve erkekler hangi rollerde temsil edilmektedir? Sorusuna yanıt olarak ortaya çıkan sonuç, internet gazetelerinde kadınların en fazla «Üçüncü Sayfa-Magazin Nesnesi" rolünde temsil edildiği şeklindedir. Bu grupta görüntülenen kadın sayısı diğer gruplardan çok daha yüksektir. Ayrıca, bu gruptaki kadın fotoğraflarının büyük boyutlu olarak ve sayfanın görünürlüğü yüksek yerlerinde kullanılması, sayfada "Üçüncü Sayfa-Magazin Nesnesi" grubundan kadın görüntülerinin baskın olduğu bir iklim yaratmaktadır. Erkekler ise, "Doğal ve Eşit Varlık" olarak görüntülenmiştir. Bu gruptaki erkek fotoğrafı sayısı diğer gruplardakinden çok daha yüksektir. Dolayısıyla, çözümlenen internet gazetelerinde kadınların daha çok "Üçüncü Sayfa-Magazin Nesnesi" olarak, aynı gazetelerde erkeklerin ise "Doğal ve Eşit Varlık" olarak temsil edildiğini söylemek mümkündür.

e) İncelenen gazetelerde kadınlara ve erkekler hangi tür haberlerde daha çok yer verilmektedir? Sorusuna cevap aramak amacıyla yapılan taramada, internet gazetelerinde kadınların en fazla "Magazin, Sanat ve Medya" konulu haberlerde görüntülendiği ortaya çıkmıştır. Bu gruplarda görüntülenen kadınların sayısı diğer gruplardaki kadınlardan çok daha yüksektir. İkinci sırada "Bilim ve Sağlık" konulu haberler gelmektedir. "Bilim ve Sağlık" grubundaki haberler, ağırlıklı olarak kozmetik ve diyet odaklı haberlerdir. Ayrıca, internet gazetelerinde "Magazin, Sanat ve Medya" konulu haberlerde kullanılan kadın fotoğraflarının daha büyük boyutlu ve sayfada daha çok göze çarpacak şekilde kullanıldığı gözlemlenmiştir.

Erkeklerdeki duruma baktığımızda ise "Siyaset ve Hükümet" konulu haberlerde daha çok erkeklerin görüntülendiği tespit edilmiştir. Üç internet gazetesinde de erkekler "Siyaset ve Hükümet" konulu haberlerde diğer haber konularından daha görünür durumdadırlar. Bu durum ülkemizde siyasetle uğraşan kesimin genelde erkekler olmasıyla açıklanabilir. Erkeklerin daha çok siyaset gibi ciddi konularda görünür olması kadınların ise daha çok magazin gibi hafif tabir edilebilecek haberlerde konu edilmesi bir tezat oluşturmaktadır.

f) İnternet gazetelerinde yayınlanan kadın fotoğraflarının gerektiği durumda ilgili haber başlığı ve metni de dikkate alınarak değerlendirilmesi sonucunda, belli bir kadın modelinin ön plana çıkarıldığı ve kadınlara yönelik belli yaşam modeli önerilerinde bulunulduğu tespit edilmiştir. Bu kadın modelinin çözümlenen bütün internet gazeteleri için 20-35 yaş arası, eğlence sektöründe yer alan, magazin figürü ve egemen güzellik kalıplarına uygun özelliklere sahip olduğunu söylemek mümkündür. Ancak, üç internet gazetesi arasında önerilen yaşam modelleri açısından farklılıklar görülmüştür. 
milliyet.com.tr'nin kadınlara yönelik “estetik ve cinsel değeri” yüksek varlıklar olma dışında herhangi bir yaşam modeli önerisi tespit edilmemiştir. hurriyet.com.tr'de ise gelinlikle, bir erkekle öpüşürken, evinde ve bir çocukla birlikte görüntülenen kadın sayısının diğer iki internet gazetesinden daha yüksek olmasından yola çıkılarak, bu gazetenin kadınlara yönelik başarı, mutluluk ve ideal hayat önerisinin güzellik, romantik bir aşk, evlilik, çocuk ve evle özdeşleşmiş bir hayat olduğunu düşünmek mümkündür. Cinsellik vurgusunun milliyet.com.tr'den daha az, fakat hurriyet.com.tr'den daha yüksek olduğu sabah.com.tr'de de kadınlara verilen birincil mesaj öncelikle cinsel ve estetik değere sahip olmaları yönündedir. Kadınların sıkça gelinlikli ve annelikle ilişkilendirilerek görüntülendiği ve evli ve çocuklu kadınların daha görünür kılındığı dikkate alındığında, kadınlara verilen ikinci mesajın "evli ve çocuklu" bir yaşam modelini benimsemek şeklinde olduğu düşünülebilir.

g) İnternet gazetelerinde yayınlanan erkek fotoğraflarının gerektiği durumda ilgili haber başlığı ve metni de dikkate alınarak değerlendirilmesi sonucunda, belli bir erkek modelinin ön plana çıkarıldığı ve erkeklere yönelik belli yaşam modeli önerilerinde bulunulduğu tespit edilmiştir. Bu erkek modelinin çözümlenen bütün internet gazeteleri için 20-35 yaş arası, yarı vasıflı meslek sahibi, doğal ve eşit bir varlık olarak görülen, siyaset gibi ciddi işlerle uğraşan, bakımlı ve fiziksel açıdan güçlü olduğunu söylemek mümkündür.

\section{Sonuç}

Bu çalışma, internet gazetelerinde cinsiyetçi ideolojinin ve onun taşıyıcı öznelerinden biri olarak toplumsal cinsiyet kimliklerinin nasıl inşa edildiği sorusunu yanıtlamak amacıyla gerçekleştirilmiştir. $\mathrm{Bu}$ amaç doğrultusunda, internet gazetelerinde kadınların ve erkeklerin görünürlük seviyesini ve hangi kadın/erkek gruplarının ne kadar ve nasıl görüntülendiğini tespit etmek üzere internet gazetelerinde yayınlanan fotoğraflar temelinde bir içerik çözümlemesi yapılmıştır.

01.06.2017 ile 15.06.2017 tarihleri arasında yayınlanan internet gazeteleri milliyet.com.tr, hurriyet. com.tr, sabah.com.tr'nin ana sayfasında gerçekleştirilen içerik çözümlemesi sonucunda, internet gazetelerindeki kadın görünürlüğünün erkeklerden az olmadığını ortaya çıkarmıştır. Yayınlanan kadın fotoğraflarının sayısı erkeklerden daha az olmakla birlikte, fotoğraf büyüklüğü ve sayfadaki yeri dikkate alındığında kadınların genel olarak "eksik" temsil edilmediğini söylemek doğru olacaktır. Diğer taraftan, taranan üç internet gazetesinde kadınların "eksik" değil, fakat "yanlış" temsili söz konusudur. Kadının "yanlış” temsili, nüfusun küçük bir bölümünü oluşturan bir kadın grubuna büyüteç tutulurken, gerçek dünyadaki kadınların çok büyük bir kesiminin ışık tutulması gereken sorunlarıyla birlikte üzerinin örtülerek yok sayılmasından, dolayısıyla dışlanmasından kaynaklanmaktadır.

Bir diğer tespit, taranan gazeteler arasında belli farklılıklar bulunmakla birlikte, internet gazetelerinin magazin ağırlıklı bir yapıya sahip olduğu, magazin malzemesi olarak da öncelikle kadınların kullanıldığıdır. Kadınların daha çok magazin figürü olarak kullanılmasına paralel şekilde, belli yaş ve meslek gruplarındaki kadınlar belli bir temsil şekliyle sunulmuştur. Bu eğilim sonucunda, internet gazetelerinde ağırlıklı olarak eğlence sektöründe yer alan 20-35 yaş arası kadınların görünür kılındığı tespit edilmiştir. Kadın fotoğraflarının kullanıldığı haberin konusu ve görüntülenen kadınların giyiniklik seviyeleri de dikkate alındığında, internet gazetelerinde kadınların ağırlıklı olarak "magazin nesnesi" ve "cinsel nesne" şeklinde temsil edildiğini söylemek mümkündür. 
Kadınlara yönelik başarı, mutluluk ve ideal hayatönerilerinde internet gazetelerinin tümünde güzelliğin öncelikli önemine işaret edildiği görülmüştür. Kitle iletişim araçlarında yer alan kadın imgeleri, ideal kadının fiziksel görünümünü ayrıntılı olarak tarif etmekle kalmamakta, davranış özellikleriyle ilgili "ideallerin" de neler olduğunu göstermektedir. Buna göre, kadınlar için başarı çalışarak değil güzellikle kazanılır. Kadınların öncelikli hedefi standart güzellik kalıplarına uygunluklarını kaybetmemeleri şartıyla, aşk, evlilik, çocuk ve evle sınırlı bir hayata kavuşmaktır.

Erkeklerin internet gazetelerindeki temsil boyutuna bakıldığında, toplumsal ve kültürel olarak şekillenen erkeklik değerlerinin haber içeriği üzerinden yeniden üretildiği görülmektedir. İncelenen internet gazetelerinde ön plana çıkan erkeğin temsil özellikleri; modayı ve teknolojiyi takip eden, delikanlı, baba ve eş, sert, dayanıklı, güçlü erkek şeklindedir ve ataerkil düzendeki erkek egemenliği bu temsil özellikleriyle meşrulaştırılmıştır.

Erkeğin temsil biçimlerinden olan modayı ve teknolojiyi takip eden erkek kimliğinde erkeklerin de kadınlar gibi tüketim kültürüne dahil olduğu gözlemlenmiştir. Tüketen erkek modeliyle beraber geleneksel değerlere bağlı erkek modelinin yanında modern erkek algısının da giderek güçlendiğini söylemek mümkündür. Artık modern erkek kimliğinin ihtiyaçları da tüketim kültürü için önem kazanmıştır. İncelenen internet gazetelerinin haber içeriklerinde de erkeğin güzelleşme ve estetik kaygısı sık sık karşımıza çıkmıştır.

Araştırmada elde edilen veriler, en azından tarama yapılan internet gazetelerinde uygulanan temsil politikalarının, toplumsal cinsiyet kalıplarının ve cinsiyetçiliğin yeniden üretilip pekiştirilmesine katkıda bulunan bir eğilime sahip olduğunu göstermektedir. Başka bir ifadeyle, internet gazetelerinin kadına ilişkin temsil politikaları sorunlu bir durum arz etmektedir. Durumun sorunlu olması, bir yönüyle "temsil etiği" olarak ifade edilebilecek "eşit ve doğru temsil" ilkesinin kadınlara uygulanmaması, bir yönüyle ise kadınlar ve kadın kimliği üzerinde yaptığı etkiden kaynaklanmaktadır.

Cinsiyetçi ideoloji de diğer ideolojiler gibi yanılsamalı bilinç yaratarak belli bir sistemi korumaya ve devamlılığını sağlamaya çalışmaktadır. Cinsiyetçi ideolojinin koruduğu ve devamlılığını sağladığı sistem ataerkil sistem, bilinç yanılsamasında kullandığı en önemli araç ise kadın ve erkekler için kurgulanmış toplumsal cinsiyet rolleridir. Cinsiyetçi ideolojinin, mevcut ataerkil sistemi doğal ve meşru olarak göstermesi, ayrı birer kategori olarak gösterilen kadın ve erkeklere yine birbirinden ayrı toplumsal cinsiyet rolleri atfetmesi yoluyla gerçekleşmektedir. Kadın ve erkeklerin toplumsal cinsiyet rollerini benimseyip içselleştirmesi cinsiyetçi ideolojinin varlığını sürdürmesinde birincil öneme sahiptir. Çünkü cinsiyetçi ideoloji de diğer ideolojiler gibi bilinç taşıyıcı öznelerin varlığını gerektirir. Kadın ve erkekler toplumsal cinsiyet rollerini benimseyip içselleştirdikçe cinsiyetçi ideolojinin taşıyıcı özneleri haline gelmekte, böylece cinsiyetçi ideoloji kadın ve erkekleri ataerkil sistemin gereklerine uygun özneler olarak inşa etmektedir. 


\section{Kaynakça}

Akınerdem, F. (2016). Türkiye Medyasında Kadınların Temsili: Gazete ve İnternet Haberciliği. https://hrantdink.org/tr/ asulis/yayinlar/72-medyada-nefret-soylemi-raporlari/457-turkiye-medyasinda-kadinlarin-temsili-gazete-ve-internethaberciligi. Erişim Tarihi: 02.12.2018.

Armstrong, C. (2006). "Writing About Women: An Examination of How Content for Women Is Determined in Newspapers." Mass Communication and Society, (4) 9: 447-460.

Büyükbaykal, C. I. (2011). "Medyada Kadın Olgusu.” İstanbul Üniversitesi Illetişim Fakültesi Dergisi, (28): 19-30.

Çelenk, S. (2005). Televizyon, Temsil, Kültür: 90’ı Yıllarda Sosyokültürel İklim ve Televizyon İçerikleri. Ankara: Ütopya Yayınları.

Durham, Meenakshi G. ve Kellner, D. (2006). Media And Cultural Studies: Keyworks. Malden: Blackwell Publishing.

Elo, S. ve Kyngash, H. (2008). "The Qualitative Content Analysis Process.” Journal of Advanced Nursing. (62): 107-115. Giddens, A. (2000). Sosyoloji. H. Özel ve Cemal G. (çev.). Ankara: Ayraç Yayınları.

Glaser, B. ve Anselm, S. (2006). The Discovery of Grounded Theory: Strategies for Qualitative Research. New Burnswick: Aldine Transaction.

GMMP (2015). "The Global Media Monitoring Project," http://whomakesthenews.org/gmmp/gmmp-reports/gmmp2015-reports. Erişim: 20 Mayıs 2017.

Gökçe, N. (2001). l'çerik Çözümlemesi. Konya: Selçuk Üniversitesi Yayınları.

Grossberg, L. (2006). Media Making: Mass Media in a Popular Culture. California: Sage.

Hall, S. (1998). "Anlamlandırma, Temsil, ideoloji, Althusser ve Postyapısalcı Tartışmalar." Kitle Iletişim Kuramları. Erol Mutlu (der.) içinde. Ankara: Ankara Üniversitesi İletişim Fakültesi Yayınları.

Hall, S. (2003). “İdeolojinin Yeniden Keşfi: Medya Çalışmalarında Baskı Altında Tutulanın Geri Dönüşü.” Medya, İktidar, ideoloji. Mehmet Küçük (der.) içinde. Ankara: Ark Yayınları.

Krippendorff, K. (2004). Content Analysis: An Introduction to Its Methodology. California: Sage.

Kuruoğlu, H. (2000). "Kadın Medyada Nasıl Yer Alıyor?." http://www.kazete.com.tr/arsiv/2000/19/yazarlar/huriye.html. Erişim Tarihi: 02.12.2018.

Kuruoğlu, H. ve Akçora, E. (2017). "Türkiye de televizyon ana haber bültenlerinde haber öznesi olarak kadın kimliklerinin kıyaslamalı incelenmesi- 2001 ve 2016." Abant Kültürel Araştırmalar Dergisi (2) 4: 175-200.

Larson, S. (2006). Media \& Minorities: The Politics of Race in News and Entertainment. Maryland: Rowman \& Littlefield. MEDiZ (2008). "Medyada Kadınların Temsil Biçimleri Araştırması" http://bianet.org/files/doc_files/000/000/015/original/ mediz_rapor_0806.doc. Erişim Tarihi: 07.02.2017.

Miles, M. ve Huberman, M. (1994). Qualitative Data Analysis. California: Sage.

Neuendorf, Kimberly (2002). The Content Analysis Guidebook. California: Sage.

Price, J. (1998). Advanced Studies In Media. Cheltenham: Nelson Thornes.

Rose, G. (2002). Visual Methodologies. California: Sage.

Sabuncuoğlu, A. (2006). Televizyon Reklamlarında Toplumsal Cinsiyet. Yayınlanmamış Yüksek Lisans Tezi. İzmir: Ege Üniversitesi SBE.

Said, E. (1999). Şarkiyatçılık. İstanbul: Metis Yayınları.

Saktanber, A. (1995). "Women in The Media in Turkey: The Free, Available Woman or The Good Wife and Selfless Mother?." Women in Modern Turkhis Society: a Reader/ Edite. Şermin Tekeli (der.) içinde. London: Zed Books.

Signorielli, Nancy (1997). Reflections of Girls in the Media: A Content Analysis A Study of Television Shows and Commercials, Movies, Music Videos, and Teen Magazine Articles and Ads. An Executive Summary. California: Henry J. Kaiser Family Foundation.

Tanrı̈ver, H. U. (2007). "Medyada Kadınların Temsil Biçimleri ve Kadın Hakları İhlalleri.” Kadın Odakıı Habercilik. Sevda 
Alankuş (der.) içinde. İstanbul: IPS İletişim Vakfı Yayınları.

Tanrıöver, H. U. (2013, Şubat). "Medyada Şiddet ve Cinsiyetcilik, Erkek Şiddeti”. Erkek Şiddeti, Görünürlük ve Medya Konferansı. İstanbul: İsveç Araştırma Enstitüsü. 1. Cilt: 54-69.

Weber, R. (1990). Basic content analysis. California: Sage.

Wimmer, R. ve Dominick, J. (2011). Mass Media Research: An Introduction. Boston: Wadsworth Cengage Learning.

Yıldırım, A. ve Şimşek, H. (2008). Sosyal Bilimlerde Nitel Araştırma Yöntemleri. Ankara: Seçkin Yayıncılık. 